\title{
Rule of Law, Economic Growth and Shadow Economy in Transition Countries
}

\author{
Thi Thuy Huong LUONG*, Tho Minh NGUYEN**, Thi Anh Nhu NGUYEN*** \\ Received: February 8, 2020 Revised: February 24, 2020 Accepted: March 1, 2020.
}

\begin{abstract}
The paper aims to investigate the interactions between rule of law, economic growth and the shadow economy in 18 selected transition economies. This study uses annual data over the period 2002-2015 for 18 transition countries to estimate the effects of rule of law and other factors on the size of shadow economy. The transition country group is classified based on International Monetary Fund resources and is selected on the basis of the availability of data. The data examined in this research are derived from the World Bank, Worldwide Governance Indicators project and Working Paper from International Monetary Fund. This study employs GMM method. The results show that the economic growth indicators have negative and statistically significant impact on the shadow economy. Additionally, these results also reveal that in transition countries the size of shadow economy is negatively related to the quality of rule of law. However, the findings of this research also point out that there are positive relationships between inflation, public expenditure and the size of shadow economy. Hence the results from this study suggest that the size of shadow economy could be controlled by improving the effectiveness of rule of law and the growth of economy particularly in transition countries.
\end{abstract}

Keywords : Shadow Economy, Economic Growth, Rule of Law, Transition Countries

JEL Classification Code: E26, O47, K29, P27.

\section{Introduction}

At present the activities affiliated with the shadow economy occur all around the world: in developed, transition, and poor economies. This growing tendency towards the shadow economy has become so strong that the majority of the communities have taken action to take control of the shadow economy activities by providing practical solutions including education, penalty or prosecution. In order to exploit resources successfully, a

${ }^{*}$ First Author. Lecturer, Faculty of Finance-Banking, Ho Chi Minh City Open University, Vietnam. Email: huong.Itth@ou.edu.vn

**Lecturer, Faculty of Finance-Banking, Ho Chi Minh City Open University, Vietnam. Email: tho.nm@ou.edu.vn

${ }^{* * *}$ Corresponding Author. Lecturer, Faculty of Finance-Banking, Ho Chi Minh City Open University, Vietnam [Postal Address: 35-37 Ho Hao Hon, District 1, Ho Chi Minh City, 700000, Vietnam]

Tel: +84 948368177, Email: nhu.nta@ou.edu.vn

(c) Copyright: The Author(s)

This is an Open Access article distributed under the terms of the Creative Commons Attribution Non-Commercial License (http://Creativecommons.org/licenses/by-nc/4.0/) which permits unrestricted noncommercial use, distribution, and reproduction in any medium, provided the original work is properly cited. country is required to have a deep understanding of the shadow economy. In other words, it is essential to be fully aware of the size and role of the shadow economy, those involved and the rate of occurrence of its activities. Hence an increasing number of empirical studies on the size of global shadow economy and its expansion has risen quickly (Feld \& Schneider, 2010; Schneider 2011, 2015, 2017; Schneider \& Williams 2013; Williams \& Schneider, 2016; Hassan \& Schneider, 2016). It is possible that the issues concerning the shadow economy are complex and manyfaceted so most research conducted in this field mainly shows how to measure the shadow economy and identifies several characteristics of shadow activities (Schneider \& Enste, 2013; Mikulic \& Nagyszombaty, 2013; Schneider \& Hametner, 2013). Other research investigates the impact of the shadow economy (Eilat \& Zinnes, 2002; Schneider \& Enste, 2013; Krstic \& Schneider, 2015).

Based on the estimation from Schneider (2005), in the developing and transition economies shadow economies occupy 40 percent of production while this figure is just around 17 percent in advanced economies. This means that the size of underground economy differs among countries 
with different levels of economic development. In addition, Schneider and Enste (2013) also found in some countries the shadow economy takes over 60 percent of their production such as Azerbaijan (63.3\%), Bolivia (68.1\%) and Peru (63.3\%). Recently, Medina and Schneider (2017) have indicated that there is a decrease in this figure for both developed and developing countries.

However, while this phenomenon has attracted a lot of interest from researchers to recognize the determinants of shadow activities, it is still debatable how this informal economy correlates with the formal one. In addition, it is also difficult to conclude exactly whether the shadow economy has an impact on economic growth in transition countries (Eilat \& Zinnes, 2002; Feld \& Schneider, 2010; Schneider, 2005, 2011; Schneider \& Enste, 2000; Williams \& Schneider, 2016). Furthermore, according to Legalist school of thought about the shadow economy, institutional quality is considered a determinant of this sector.

As an illustration of this, many studies have proved that institutional quality has negative influence upon the shadow economy (Torgler \& Schneider, 2009; Dreher, Kotsogiannis, \& McCorriston, 2009; Dreher \& Schneider, 2010 and Hassan \& Schneider, 2016). Moreover, it is also argued that inferior institutional quality, for example the ineffectiveness of governance and rule of law, could be the main reasons for taking part in the shadow economy. Particularly, according to the data collected from transition countries and OECD, Johnson, Kaufmann, and Schleifer (1998) indicate that the size of the shadow economy is positively associated with the level of corruption and the quality of rule of law. These researchers believe that low quality of rule of law, slack regulations and inadequate supervision could result in a larger number of firms working in the shadow economy as officials could exploit this low institutional quality to get involved in corruption.

Accordingly, the purpose of this research is to shed light on the association between the shadow economy and economic growth by using the panel data of transition economies in the period 2002-2015. Moreover, this paper also considers whether rule of law has any effect on the shadow economy or not in order to suggest a new indicator to control the shadow economy because according our knowledge, there still has not been any empirical study on the impact of rule of law on the shadow economy. Hence the contributions of this study are different from prior studies by exploring the relationship between economic growth and underground economy. Besides, this research also emphasizes the rule of law indicator in an empirical analysis in the context of different transition economies. In other words, this research provides empirical evidence of the linkage between economic growth and the size of the informal economy in transition economies and specifically detects the influence of rule of law indicator.
To attain this objective, this research implements the following strategy. The sample of 18 transition countries over the period 2002 to 2015 is gathered to obtain data about rule of law, economic growth, the shadow economy, and other control variables. Then a dynamic model is employed to estimate the relation among these variables by using Generalized Method of Moments (GMM) method.

This paper is organized as follows: the next section presents literature review. Then methodology and data are described in detail in section 3. Results and discussion are presented in section 4. The final section is conclusion offering policy implications and further research suggestions.

\section{Literature Review}

\subsection{Introduction to Shadow Economy}

The shadow economy has been observed as a phenomenon for more than four decades also named as unofficial, hidden, underground, or black market. Economists globally try to define it, estimate the extent of it and recommend either control or eliminate it. Nevertheless, underground economy is recognized that once established, it is notoriously difficult to ignore (Schneider, 2000).

In recent years, it is widely accepted that every national economy is dual which comprises official sector and unofficial sector (Schneider \& Enste, 2013). The latter is divided into two groups: household sector (self-sufficient economy) and the shadow economy (products and services are traded through markets as usual). Most papers exclude the self-sufficient activities from the concerns as they are non-market economic activities but legal (Eilat \& Zinnes, 2002; Schneider \& Hametner, 2013; Zaman \& Goschin, 2015). The shadow economy comprises illegal activities such as illicit work and criminal sector (Schneider, 2000). In this paper, the given definition of the shadow economy is all economic activities (whether legal or illegal) dealt on market transactions, but not recorded in the calculation of the gross national/domestic product for monetary, regulatory and institutional reasons (Wu \& Schneider, 2019).

To estimate the extent of the shadow economy, Schneider and Enste (2013) infers three common following approaches: the direct method (through the surveys); the indirect method (via national accounting, monetary approaches and physical input method); and the model approach. Every technique has pros and cons itself. Another difficulty in measuring the hidden activities is the unavailability and unreliability of data. As a result, one research may use more than one approach applied for interrupted time. 
Regarding to the economic causes and consequences of the shadow economy, Schneider and Enste (2013) have classified into four main reasons: Firstly, tax burden is one of the most popular causes of the growth of hidden activities. Both average tax rate and marginal tax burden are denoted to have strong correlation. It is pointed that the more taxation system is set up by politicians, the more encouragements for individuals and firms operate in black markets (Buehn, 2011).

The second reason is the extent of regulations, especially the conditions of labor force such as the rule of working hour per week, early retirement, or restrictions on foreigners.

Eilat and Zinnes (2002); Mikulic and Nagyszombaty (2013); and Schneider and Hametner (2013) emphasize the density of regulatory perception as the key determinant of the shadow economy in transitional countries. It is stated that if the governance and rule of law are feeble, individuals and firms may run their business without supervision. Bribes and corruption are undesirable consequences as lacking of bureaucrats' control.

Thirdly, social security is also considered another occasion for underground activities to become larger. On the subject of the firms' expenditure, in the unofficial sector, they may cut off different kinds of insurance such as pension, unemployment and health protection and the health care from employees. Based on the previous statistics, Armenia has the highest proportion of illicit work, followed by Croatia and Bulgaria with 75.5\%, 70\% and 63\% of the official labor market in respectively. In general, the underground labor force in transition countries is approximately $49 \%$ of the official worker market and $23.9 \%$ of population (Schneider \& Enste, 2013).

The final reason for the shadow economies is the transfer payments which involve the social welfare and unemployment benefits. As Krstic and Schneider (2015) also concur that the social welfare system can demoralize individuals and firms from working in the official sector. On the basic of causes, the outcomes of the shadow economy have been noticed decreasing public goods, detering foreign participations, reducing competition in a country, distorting resource use and worsening the residents' morals in a country (Eilat \& Zinnes, 2002). However, the shadow economy is assessed as unwelcomed activities due to the social distortions on the one hand. On the other hand, it can be regard as part of transform process to revive or promote economies (Eilat \& Zinnes, 2002; Schneider \& Enste, 2000).

\subsection{Economic Growth in Transition Countries}

According to the newest report of European Bank for Reconstruction and Development (EBRD, 2019), the number of transition countries have being changed. It has expanded from 25 countries in 1990s to 35 countries in 2019. After the collapse of Union of Soviet Socialist Republics (USSR), a number of countries in the European and Central Asia fail to economic recession with high inflation and unemployment rate, the degradation of social services, the suspension of crucial supply chains (Schneider \& Enste, 2013). The real GDP in the years 1989-90 was in dramatic downturn (Anno \& Villa, 2013). The decision to reform from the central planned economy to open market is given to wake the economy up. As most of them are the republics of former Soviet Union, they were socialism and changed to capitalist regime. In some of them, the institutional revolution is not over yet, they are postsocialist economies (Piatkowski, 2002). Although their economic similarity is to market-oriented economy, the starting time and the way to innovate amongst countries are various. As a result, the effects and results of restructuring on economic growth are dissimilar. For example, while the economies on Czech Republic, Hungary and Poland have achieved remarked success, it seems no improvement in Commonwealth of Independent States (CIS) and other Eastern European countries (Lee \& Jeong, 2006). In spite of that, the structural reform is confirmed to have initial contributions to stimulate the economic growth in transition countries (Tabaghua, 2018).

According to Eilat and Zinnes (2002), the shadow economy in transition countries has all features of OECD countries as well as less-developed countries (such as the heavy burden of tax and labor regulations, tax evasion, regulation avoidance, corruption, the disbelief of citizens in governance). Moreover, it has the unique properties, such as: (1) not only the private sector but also the state entrepreneurs involve in unofficial market; (2) the hidden activities are vague as majority of them are from rural or household supply; (3) they mainly use barter and foreign currencies for the exchange; (4) they could be legal and quite sensitive to economic incentives from governments (Schneider \& Enste, 2013). In the following section, through previous researches, the correlation between the shadow economy and economic growth is reviewed.

\subsection{Economic Growth, Rule of Law and Shadow Economy}

The presence of the shadow economy has expanded not only in any particular area but also worldwide. In spite of that, the extent of these unofficial activities differentiates in group of nations in every period of time. Focusing on the transition countries, for the years 1989 to 1995 , Schneider and Enste (2000) pointed out that the average size of unofficial sector has expanded nearly in double, from $17 \%$ in the years $1989-90$ to $30 \%$ in 1994-95. In which, it is 
dedicated that the former Soviet Union markets have greater shadow economies, with $25 \%$ of GNP compared to the former Eastern bloc economies, with 20\% of GNP in the period of 1989-93. The largest shadow economies are Russia, Ukraine (where the percentage of shadow economy more than $40 \%$ of GNP) and the small hidden markets can be named as Poland, Slovakia and Romania (between 7\% and $18 \%$ of GNP). The difference is explainable due to the chosen way to develop in fast or in gradual pace. Another reason is that the starting time of evolution did not occur at the same time, the relationship between shadow economy and economic growth presents dissimilar tendency at country level. It could be in positive, negative or even nonlinear association (Adam \& Ginsburgh, 1985; Loayza, 1996; Krstic \& Schneider, 2015).

A number of studies have revealed the linear correlation. According to Zaman and Goschin (2015), when observe the link between the shadow economy and economic growth in Romania for the years 1999-2012. The OLS regression is applied on the basic of three indicators: the unofficial economy calculated in Euro per inhabitant, on percentage of GDP and compared every state of EU total EU-shadow economy. Though the result did not state the significant influence of unofficial activities on economic growth, it is found the relatively positive correlation between GDP and the shadow economy. In the long-run, it is illustrated that the official and the second economy are going to move on the same disposition. Also observing the Romania's situation, the research of Davidescu Strat, and Paul (2015) reveals great differences: applying Gutmann approach for quarterly data, it is demonstrated a U-shaped curve correlation between the ratio of hidden economy and official economy. The similarity as well as the limitation of both above studies are they are not diversified the determinants of the economic growth or the shadow economy. It is just relying on GDP (Zaman \& Goschin, 2015; Bong \& Premaratne, 2019) or the percentage of currency to overnight deposits (Davidescu et al., 2015).

Loyaza (1996); Eilat and Zinnes (2002) demonstrate the negative relationship between the shadow economy and economic development by a range of casual variables. The former investigates the data from Latin America in the early 1990s, mentioned determinants of the shadow economy are the tax burden, restrictions on the labor force, corruption, rule of law and quality of authorities. Eilat and Zinnes (2002) examine the shadow economy in transition countries with a number of rich sources of casual factors including: the quantity of tax revenues, unemployment, inflation, openness, levels of investment, overregulation, corruption, rule of law, the quality of bureaucracy, the level of government expenditure on health and education services, the use of local currency, capital markets, quality of banking sector, infrastructure and human development.
Using the modified total electricity approach, the general result is that when the official GDP decrease one dollar, the hidden economy rise 31 cents, except in few transition countries where the restructuring has not yet emerged. The negative correlation is found between the shadow economy and the use of local currency, the quantity of tax revenues, openness, levels of investment, rule of law, human development, the quality of governance, capital markets, banking sector quality, infrastructure. In contrast, there is positive relationship between unemployment, overregulation, corruption, inflation and the underground economy. On the rest, the level of government expenditure on health and education is proved not related to the size of the shadow economy.

Lackó (2000); Anno and Villa (2013) point out that the linear correlation is merely suitable in the short-term when the economic reforms may not yet start in some transition countries. In the rest of post-socialist countries apart from CIS countries, the relationship between the economic growth and the unofficial market in the long-run tends to present a reversed U shaped curve (He, 2018). In regard of determinants of hidden economy, Johnson, Kaufmann, and Schleifer (1997) found that liberalization is significantly related to the unofficial sector. The negative relationships are indicates between the share of privatization, the quality of taxation, corruption, regulation, the supply of law and the share of shadow activities. Lackó (2000) also assesses the determinants of hidden economy such as the quantity of regulation, the force of bureaucracy, the tax burden, corruption and rule of law.

However, the results are opposite to Johnson et al. (1997). It is found that the size of shadow economy is relatively positive with greater regulation and officials' discretion, tax burden (tax rate and tax administration included), and corruption. The most current nonlinear relationship between the shadow economy and GDP per capita is emphasized in IMF Working Paper 2019 prepared by $\mathrm{Wu}$ and Schneider (2019). The paper indicates that the shadow economy tends to expand when economic growth exceeds a given threshold or at least presents in permanent. These discoveries are suitable to the features of the shadow economy: it may be considered as part of an evolutionary process in the short-run. However, they have notoriously dangerous effects on economy with out-control illicit work and criminal activities in the long-term.

As mentioned above, the relationship between the shadow economy and economic growth in transition countries is quite difficult to give the exact conclusion. Regarding the observed years of this paper, it may be assumed that the global economic crisis has forced more and more businesses to informal sector (Krstic \& Schneider, 2015). After realizing the potential determinants of the shadow economy, a model with following independent 
variables is attempted to evaluate the relationship between hidden economy and economic growth of 18 transition countries for the period 2002-15. "Rule of law" is the first term to be concerned as Eilat and Zinnes (2002) induced the extent of regulatory perception is the key determinant of hidden economy. In the case of lacking rule of law, the authorities tend to decide by their own discretion. It easily initiates the economy markets with bribes and corruption so that, either the insufficiency of rule of law or lax "control of corruption" causes firms to move unofficial sector.

Furthermore, the "public expense" is put on consideration to investigate the connection between the presence of shadow economy and the quality as well as the quantity of public goods and services. According to Choi and Thum (2005), the amount of money spending on public infrastructure is the most important element for the economic growth. Analyzing the interaction between hidden activities and expense of governance, it is supposed that the association of the former with economic growth is revealed.

In addition, two favored indicators in most of studies are the "GDP growth" and the quantity of "tax revenues" appraised (Buehn, 2011; Schneider \& Hametner, 2013; Jamalmanesh, Meidani \& Mashhadi, 2014). Next, the level of investment (Johnson et al., 1997; Erum, Hussain, \& Yousaf, 2016), especially "foreign direct investment - FDI" is observed because of its potentially negative association with the shadow economy. Last but not least, "inflation rate" is the final determinant gauged in the model because of its crucial relationship to economic growth (Tabaghua, 2018).

\section{Data and Methodology}

\subsection{Data}

This study uses annual data over the period 2002-2015 for 18 transition countries to estimate the effects of rule of law and other factors on the size of shadow economy. The transition country group is classified based on International Monetary Fund resources and is selected on the basis of the availability of data. The countries investigated in this paper will be listed in the Appendix.

In the regression equation, the dependent variable examined in this paper is the size of shadow economy which is presented by the percentage of GDP and collected from Medina and Schneider (2018). The main independent variables are Rule of Law which is calculated in the Worldwide Governance Indicators (WGI) project by Kaufmann and Kraay (2016) and Gross domestic product which represents economic growth and collected from World Bank (2016). Rule of Law element reflects perceptions of the extent to which agents have confidence in and abide by the rules of society, the quality of contract enforcement, property rights, the police, the courts, the likelihood of crime and violence. The estimate of governance ranges is from approximately -2.5 (weak) to 2.5 (strong) and this measure has been rescaled from 0 to 5 respectively. Besides, inflation, public expenditure, tax revenue, foreign direct investment and control of corruption index are also added in the empirical model as control variables in the empirical analysis. The table below presents a short description statistics and sources of all variables (see Table 1):

The selected transition countries have the mean shadow economy measured by \% GDP stood at 32.87 from minimum value at 11.74 to maximum value at 68.46 . Besides, the mean value of Rule of Law in these countries reached 2.07 which is by far lower compared to the mean value 2.5 of ranges $0-5$. Similarly, control of corruption index is 1.98 in the mean value and this number presents high level of corruption. This could be explained by the institutional environment after transition period in these countries.

Table 1: Summary statistics and the sources of data

\begin{tabular}{|c|c|c|c|c|c|}
\hline Variable & Obs & Mean & SD & $\begin{array}{l}\text { Min - } \\
\text { Max }\end{array}$ & Source \\
\hline $\begin{array}{l}\text { Shadow } \\
\text { Economy } \\
(\% \text { GDP })\end{array}$ & 251 & 32.9 & 12.3 & $\begin{array}{l}11.7- \\
68.5\end{array}$ & $\begin{array}{c}\text { Medina, L., } \\
\text { Schneider, } \\
F . \\
\text { (2018) }\end{array}$ \\
\hline $\begin{array}{l}\text { Rule of Law: } \\
\text { ranges from } 0 \\
\text { (weak) to } 5 \\
\text { (strong) }\end{array}$ & 252 & 2.1 & 0.6 & $\begin{array}{l}1.2- \\
3.5\end{array}$ & $\begin{array}{c}\text { Kaufmann } \\
\text { \& Kraay } \\
\text { (2016) }\end{array}$ \\
\hline $\begin{array}{c}\text { Gross domestic } \\
\text { product } \\
\text { (billion US\$) }\end{array}$ & 252 & 449 & 1,486 & $\begin{array}{c}1.7- \\
11,016\end{array}$ & $\begin{array}{l}\text { World } \\
\text { Bank } \\
(2016)\end{array}$ \\
\hline $\begin{array}{l}\text { Inflation } \\
(\% \text { GDP })\end{array}$ & 252 & 6.8 & 7.6 & $\begin{array}{l}-1.4- \\
59.2\end{array}$ & $\begin{array}{l}\text { World } \\
\text { Bank } \\
\text { (2016) }\end{array}$ \\
\hline $\begin{array}{c}\text { Public } \\
\text { Expenditure } \\
\text { (billion US\$) }\end{array}$ & 252 & 66 & 204 & $\begin{array}{l}0.2- \\
1,546\end{array}$ & $\begin{array}{l}\text { World } \\
\text { Bank } \\
\text { (2016) }\end{array}$ \\
\hline $\begin{array}{c}\text { Tax Revenue } \\
(\% \text { GDP })\end{array}$ & 225 & 15.3 & 6.5 & $\begin{array}{l}0.3- \\
28.6\end{array}$ & $\begin{array}{l}\text { World } \\
\text { Bank } \\
(2016)\end{array}$ \\
\hline $\begin{array}{l}\text { Foreign Direct } \\
\text { Investment } \\
\text { (billion US\$) }\end{array}$ & 252 & 14.9 & 44.9 & $\begin{array}{c}-20.9- \\
291\end{array}$ & $\begin{array}{l}\text { World } \\
\text { Bank } \\
\text { (2016) }\end{array}$ \\
\hline $\begin{array}{l}\text { Control of } \\
\text { Corruption } \\
\text { Index: } 0 \text { (totally } \\
\text { corrupt) }-5 \\
\text { (not corrupt) }\end{array}$ & 252 & 1.97 & 0.53 & $\begin{array}{c}1.19- \\
3.29\end{array}$ & $\begin{array}{c}\text { Kaufmann } \\
\text { \& Kraay } \\
\text { (2016) }\end{array}$ \\
\hline
\end{tabular}




\subsection{Empirical Analysis}

In this paper, several panel data methodologies are adopted to examine the relationship between rule of law and the size of shadow economy in transition countries: OLS, fixed effects estimation, random effects estimation and system GMM. The empirical model can be written as:

$$
\begin{aligned}
S E_{i, t}=\alpha+\beta_{1} G D & P_{i, t}+\beta_{2} I F_{i, t}+\beta_{3} P E_{i, t}+\beta_{4} T R_{i, t} \\
& +\beta_{5} F D I_{i, t}+\beta_{6} C C I_{i, t}+\beta_{7} R L_{i, t}+\varepsilon_{i, t}
\end{aligned}
$$

Where;

SE: Shadow economy; GDP: Gross domestic product; IF: Inflation; PE: Public expenditure; TR: Tax revenue; FDI: Foreign Direct Investment; CCI: Control of Corruption Index; RL: Rule of Law; $\varepsilon_{i, t}$ is an error term.

Primarily, Pooled-OLS, fixed effects and random effects regression are used to find whether variables affect the size of shadow economy or not? Then, to indicate a more reliable model, which is the fixed or random effects model, we use Hausman test with the null hypothesis $\hat{\beta}_{F E M}=$ $\hat{\beta}_{R E M}$. If the result of Hausman test is p-value $<\alpha$, the null hypothesis is rejected and fixed effects model is more suitable compared to random effects model and vice versa. Besides, to control the endogenous problem between independent variables and dependent variables, the authors use the GMM estimation for panel data based on the method of Arellano and Bond (1991). As we all know, the advantages of the least effective square estimation method (OLS) are not too complicated. This method is used popularly in econometric field. With some initial assumptions, this method easily identifies effective, nonbiased and stable estimates. However, when researching time series data, the data may violate one or several assumptions of OLS. Then, the estimates will be biased, unstable and it would be wrong to use them for analysis. One of the most common types of violation is the endogenous phenomenon, where the estimated coefficient (or variable) correlates with the residual.

In the case of the correlation between independent variables and residuals exists, this can be solved by estimating an equation that uses tool variables. The idea of this method is to find a set of variables, called instrument variables that satisfy both conditions: (1) correlated with the explanation variables in the equation and (2) not correlated with residual. Such instrumental variables are used to eliminate the endogenous problem. Furthermore, the Sargan test for over-identifying restriction and the Arellano and Bond test for second order correlation in the first differenced residuals are carried out on the system GMM estimation to ensure that the instruments are not correlated with the residuals. Therefore, GMM method is widely employed in research papers to overcome the endogenous phenomenon with high accuracy.

\section{Results and Discussion}

The correlation matrix in Table 2 is analyzed to consider the relationship among variables in the empirical model. In general, it is clear that the shadow economy have negative correlation with the rule of law and GDP variables. In addition, there are adverse influences between most control variables and the size of shadow economy. Meanwhile, only inflation and tax revenue exert positive impacts on shadow economy.

Table 2: Correlation matrix

\begin{tabular}{|c|c|c|c|c|c|c|c|c|}
\hline & SE & GDP & IF & PE & TR & FDI & CCI & RL \\
\hline SE & 1 & & & & & & & \\
\hline GDP & -.61 & 1 & & & & & & \\
\hline IF & .25 & -.03 & 1 & & & & & \\
\hline PE & -.55 & .98 & -.02 & 1 & & & & \\
\hline TR & .11 & -.12 & .19 & -.15 & 1 & & & \\
\hline FDI & -.61 & .88 & -.05 & .86 & -.12 & 1 & & \\
\hline CCI & -.34 & .19 & -.22 & .28 & -.48 & .28 & 1 & \\
\hline RL & -.41 & .20 & -.28 & .28 & -.56 & .29 & .86 & 1 \\
\hline
\end{tabular}

The main empirical results of this paper are summarized in Table 3, which includes OLS, fixed effects, and random effects regression sequentially. It is clear that although there is a difference in influence level but in general all the results of four methods demonstrate the existence of a negative linkage and statistical significance between rule of law, gross domestic product and the size of shadow economy. Besides, the positive bond of public expenditure and shadow economy is also indicated. Foreign direct investment and control of corruption have no statistical significance and effect signal on the size of shadow economy. This result is not the same as the researches of Nikopour, Habibullah, Schneider, and Law (2009); Davidescu and Strat (2015); and Ali and Bohara (2017) which find that higher FDI level lead to a decrease in the size of shadow economy. A huge number of previous studies also reveal that more corruption is one of the reasons which increases shadow economy size (Johnson, Kaufmann, \& Zoido-Lobaton, 1998; Dreher et al., 2009; Huynh \& Nguyen, 2019). However, there is a drawback point which needs to be discussed that these studies focus only on a specific country or using a general research sample data which are no distinction between countries by developed, developing, transition or non-transition.

Then, the Hausman Test is adopted and the result shows that $\mathrm{p}$-value value is greater than 0.01 , the null hypothesis is 
rejected so the random effects model (REM) is more appropriate compared to the fix effects model (FEM).

After random effects (REM) regression, the residual $u_{i t}$ for the regression equation is estimated to examine the endogenous feature of each independent variable. The results confirm that the model suffers from endogenous phenomena and in order to handle this problem, the GMM method for panel data is proposed by Arellano and Bond (1991). Based on this method, a lagged variable of dependent variable which is considered independent variable and a lagged variable of the endogenous variables will be added in the model as instrumental variables.

After using the GMM Arellano and Bond method, the result overcomes the model's restrictions and shows that the main independent variables studied are rule of law and GDP which are negatively correlated with the size of shadow economy. Specifically, an increase $1 \%$ in confidence and abide by the rules of society will lead to lower $0.088 \%$ in the size of shadow economy. This result is statistically significant at the $5 \%$ level and which is entirely in line with the theoretical background and similar to the results of previous studies. It could be explained that weak rule of law, regulatory burden or lax regulations in these countries are considered as consequences of the low institutional quality and incompatible supervision system right after transition period. This generates disadvantage problems in terms of commercial contracts, economic activities and asymmetric information leading individuals and corporates to reduce their official activities and tend to operate in the underground.

The adverse impact of rule of law on shadow economy was found in transition countries supports the point of views that institutional quality is a main element to determine the shadow economy which is empirically confirmed by researches which are investigated in 19 developing Asian countries (Huynh \& Nguyen, 2019) and 37 developing Asian countries (Jamalmanesh et al., 2014) or bigger sample data with 57 countries (Torgler \& Schneider, 2009), 145 countries including developing, transition, highly developed OECD countries (Dreher et al., 2009), and 157 countries (Hassan \& Schneider, 2016).

Similarly, in the adverse relationship between economic growth which is represented by GDP variable in empirical model and the shadow economy, if gross domestic product level in selected transition countries rises $1 \%$, the size of shadow economy in these countries will be abridged to $0.5107 \%$. This linkage is statistically significant at the $1 \%$ level and has more influential level compared to Rule of Law element. It is logical that a raise in GDP represents the growth in economy. This creates more job opportunities with more reliable guarantee for workers' rights in salary regimes and social insurance regulations compared with the shadow economy and attracts the workforce and agencies to migrate from the unofficial area to the official area. In the long term, this leads to the shrinkage of the size of the shadow economy.

Table 3: Summary results

\begin{tabular}{|c|c|c|c|c|}
\hline & $\begin{array}{c}\text { Pooled-OLS } \\
\text { (1) }\end{array}$ & $\begin{array}{l}\text { FEM } \\
\text { (2) }\end{array}$ & $\begin{array}{c}\text { REM } \\
\text { (3) }\end{array}$ & $\begin{array}{l}\text { GMM } \\
\text { (4) }\end{array}$ \\
\hline$S E_{t-1}$ & & & & $\begin{array}{l}0.076 \\
(0.97)\end{array}$ \\
\hline GDP & $\begin{array}{c}-0.554 * * * \\
(-10.6)\end{array}$ & $\begin{array}{c}-0.037 * * * \\
(-12.0)\end{array}$ & $\begin{array}{c}-0.376 * * * \\
(-12.3)\end{array}$ & $\begin{array}{c}-0.511^{* * *} \\
(-10.3)\end{array}$ \\
\hline IF & $\begin{array}{c}0.037 * * \\
(2.2)\end{array}$ & $\begin{array}{l}0.002 \\
(0.5)\end{array}$ & $\begin{array}{l}0.003 \\
(0.6)\end{array}$ & $\begin{array}{c}0.006^{*} \\
(1.9)\end{array}$ \\
\hline PE & $\begin{array}{c}0.433 * * * \\
(9.4)\end{array}$ & $\begin{array}{c}0.239 * * * \\
(7.9)\end{array}$ & $\begin{array}{c}0.243 * * * \\
(8.2)\end{array}$ & $\begin{array}{c}0.336^{* * *} \\
(8.3)\end{array}$ \\
\hline TR & $\begin{array}{c}-0.115^{* * * *} \\
(-4.7)\end{array}$ & $\begin{array}{c}0.005 \\
(0.3)\end{array}$ & $\begin{array}{c}0.003 \\
(0.2)\end{array}$ & $\begin{array}{c}-0.012 \\
(-0.7)\end{array}$ \\
\hline FDI & $\begin{array}{l}-0.007 \\
(-0.4)\end{array}$ & $\begin{array}{c}-0.004 \\
(-0.6)\end{array}$ & $\begin{array}{c}-0.004 \\
(-0.7)\end{array}$ & $\begin{array}{l}-0.010 \\
(-0.9)\end{array}$ \\
\hline CCI & $\begin{array}{c}-0.029 \\
(-0.4)\end{array}$ & $\begin{array}{c}0.003 \\
(0.1) \\
\end{array}$ & $\begin{array}{c}0.004 \\
(0.1) \\
\end{array}$ & $\begin{array}{l}0.028 \\
(-0.9) \\
\end{array}$ \\
\hline RL & $\begin{array}{c}-0.403 * * * \\
(-5.6)\end{array}$ & $\begin{array}{c}-0.151^{* * *} \\
(-3.9)\end{array}$ & $\begin{array}{c}-0.160 * * * \\
(-4.37)\end{array}$ & $\begin{array}{c}-0.088^{* *} \\
(-2.2)\end{array}$ \\
\hline Intercept & $\begin{array}{c}8.564 * * * \\
(29.2) \\
\end{array}$ & $\begin{array}{c}7.63^{* * *} \\
(37.1) \\
\end{array}$ & $\begin{array}{c}7.588^{* * *} \\
(36.1) \\
\end{array}$ & \\
\hline Obs & 207 & 207 & 207 & 166 \\
\hline$R^{2}$ & 0.672 & 0.788 & 0.787 & \\
\hline Adj. $R^{2}$ & 0.661 & & & \\
\hline \multicolumn{4}{|c|}{ Sargan test for over-identifying restriction: $p$-value } & 0.298 \\
\hline \multicolumn{4}{|c|}{$\begin{array}{l}\text { Sargan test for excluding group: } \\
\text { p-value }\end{array}$} & 0.699 \\
\hline
\end{tabular}

Note: $* * *, * *, *$ shows significant levels at the $99 \%, 95 \%$, and $90 \%$ respectively

The bond of the shadow economy and economic growth which is demonstrated in this paper is also consistent with Loyaza (1996), Eilat and Zinnes (2002); and Davidescu et al. (2015). However, the finding in this paper is not in line with Zaman and Goschin (2015) which supports the positive influence of economic growth on the shadow economy investigated in Romania for the years 1999-2012.

Besides, the empirical results illustrate that the control variables of model including IF, PE are also statistically significant and exert positive influences on shadow economy, while three control variables TR, FDI, CCI are not statistically significant and discussed above. Malaczewska (2013) also demonstrated that when the government increases the expenditures used for wages in formal sector, this will lead to a bigger shadow economy. Besides, the effect of inflation on the size of shadow economy in this paper is not consistent with Ahiabu (2006) which reveals the reverse direction between the change of 
inflation and the size of shadow economy.

Additionally, Sargan test determines the suitability of tool variables in the GMM model. Sargan test with the null hypothesis: The instrument variables are exogenous, meaning it is not correlated with the residual of model. From the test results, it shows that the Sargan Test for overidentifying restriction and excluding group has $\mathrm{p}$-value of 0.298 and 0.699 , respectively, greater than 0.1 . Therefore, we accept the null hypothesis that the tool variables are exogenous and suitable for the model. The Arellano and Bond test was proposed by Arellano and Bond (1991) to check the autocorrelation feature of first-order variance in GMM model. The results of Arellano - Bond test (AR (2)) are 0.134 greater than 0.1 and this rejects the hypothesis that the model has autocorrelation phenomenon at level 1. Thus, the GMM estimation overcomes the endogeneity phenomenon and maintains the correctness and efficiency of the research results. This increases the model's sustainability (see Table 3 ).

\section{Conclusions}

This paper mainly examined the linkage between rule of law, economic growth and the shadow economy of transition countries during the period 2002-2015 by estimating GMM method. The empirical results indicate that there is an effect of rule of law and other factors such as inflation, gross domestic product and public expenditure on the size of shadow economy in transition countries. Specifically, the effectiveness of rule of law is improved when the rules of society are more closely followed. This will result in a reduction in the extent of shadow economy. In addition, growth and the shadow economy have opposite signs of relationship so this finding suggests that reducing the size of shadow economy could be more beneficial for transition economies. This result is entirely in line with economic theory and the research conducted in other groups of countries.

This research contributes empirical evidence to the literature on the shadow economy and policy makers can take the results achieved into consideration in order to control the size of shadow economy by improving the quality of rule of law. In regard to suggestions for future research, the impact of institutional quality on unofficial sectors should be measured in order to define the intensive indicators of institutional quality factor.

\section{References}

Adam, M. C., \& Ginsburgh, V. (1985). The effects of irregular markets on macroeconomic policy: Some estimates for
Belgium. European Economic Review, 29, 15-33. DOI: 10.1016/0014-2921(85)90036-4

Ahiabu, S. (2006). Inflation and the underground economy. Munich Personal RePEc Archive. Retrieved December 10, 2019, from https://mpra.ub.uni-muenchen.de/1706/

Ali, M., \& Bohara, A. K. (2017). How does FDI respond to the size of shadow economy: an empirical analysis under a gravity model setting. International Economic Journal, 31(2), 159178. DOI: $10.1080 / 10168737.2017 .1314533$

Anno, R. D., \& Villa, S. (2013). Growth in transition countries. Economics of Transition, 21(3), 381-417. DOI: $10.1111 /$ ecot.12018

Arellano, M., \& Bond, S. (1991). Some tests of specification for panel data: Monte Carlo evidence and an application to employment equations. The Review of Economic Studies, 58(2), 277-297. DOI: 10.2307/2297968

Bong, A., \& Premaratne, G. (2019). The Impact of Financial Integration on Economic Growth in Southeast Asia. The Journal of Asian Finance, Economics and Business, 6(1), 107119. http://doi.org/10.13106/jafeb.2019.vol6.no1.107

Buehn, A. (2011). The shadow economy in German regions: an empirical assessment. German Economics Review, 13(3), 275290. DOI: $10.1111 / \mathrm{j} .1468-0475.2011 .00557 . x$

Choi, J. P., \& Thum, M. (2005). Corruption and shadow economy. International Economic Review, 46(3), 817-836. DOI: 10.1111/j.1468-2354.2005.00347.x

Davidescu, A., \& Strat, V. A. (2015) Shadow economy and foreign direct investments: an empirical analysis for the case of Romania. Ecoforum, 4(2), 110-118.

Davidescu, A., Strat, V. A., \& Paul, A. M. (2015). Revisiting the Size of Romanian Informal Economy Using the Gutmann Approach. Procedia Economics and Finance, 23, 1037-1045. DOI: $10.1016 / \mathrm{S} 2212-5671(15) 00546-8$

Dreher, A., \& Schneider F. (2010). Corruption and the shadow economy: an empirical analysis. Public Choice, 144(1), 215238. DOI: $10.1007 / \mathrm{s} 11127-009-9513-0$

Dreher, A., Kotsogiannis, C., \& McCorriston, S. (2009). How do institutions affect corruption and the shadow economy? International Tax Public Finance, 16(6), 773-796. DOI: 10.1007/s10797-008-9089-5

Eilat, Y., \& Zinnes, C. (2002). The shadow economy in transition countries: Friend or foe? A policy perspective. World Development, 30(7), 1233-1254. DOI: 10.1016/S0305750X(02)00036-0

Erum, N., Hussain, S., \& Yousaf, A. (2016). Foreign Direct Investment and Economic Growth in SAARC Countries. The Journal of Asian Finance, Economics and Business, 3(4), 5766. DOI: http://doi.org/10.13106/jafeb.2016.vol3.no4.57

European Bank for Reconstruction and Development. (2019). Transition Report 2019-2020. London, UK: European Bank for Reconstruction and Development.

Feld, L., \& Schneider, F. (2010). Survey on the Shadow Economy and Undeclared Earnings in OECD Countries, German Economic Review, 11(2), 109-149. DOI: 10.1111/j.14680475.2010.00509.x

Hassan, M., \& Scheider, F. (2016). Size and development of the shadow economies of 157 worldwide countries: Updated and new measures from 1999 to 2013, Journal of Global Economics, 4(3), 218. DOI: 10.4172/2375-4389.1000218 
He, Y. (2018). A Study on the Dynamic Relationship between Cultural Industry and Economic Growth. The Journal of Asian Finance, Economics and Business, 5(4), 85-94. http://doi.org/10.13106/jafeb.2018.vol5.no4.85

Huynh, C. M., \& Nguyen, T.L. (2019). Fiscal policy and shadow economy in Asian developing countries: does corruption matter? Empirical Economics, 1-17. [Online First] https://doi.org/10.1007/s00181-019-01700-w

Jamalmanesh, A., Meidani, A. A. N., \& Mashhadi, M. K. (2014). Government effectiveness, rule of law and informal economy in Asian developing countries. International Journal of Economy, Management and Social sciences, 3(10), 551-555.

Johnson, S., Kaufmann, D., \& Schleifer, A. (1997). The Unofficial Economy in Transition. Brookings Papers on Economic Activity, 1997(2), 159-239.

Johnson, S., Kaufmann, D., \& Zoido-Lobaton, P. (1998). Regulatory discretion and the unofficial economy. American Economic Review, 88(2), 387-392.

Kaufmann, D., \& Kraay, A. (2016). World governance indicators project. World Bank. Retrieved January 10, 2020 from https://info.worldbank.org/governance/wgi/

Krstic, G., \& Schneider, F. (2015). Formalizing the shadow economy in Serbia. New York, NY: Springer International Publishing.

Lackó, M. (2000). Hidden economy - an unknown quantity? Comparative analysis of hidden economies in transition countries in 1989-95. Economics of Transition, 8(1), 117-149. DOI: $10.1111 / 1468-0351.00038$

Lee, Y.-S., \& Jeong, H.-G. (2006). The determinants of economic growth of transition economies: Economic reform versus initial conditions. International Economic Journal, 20(2), 241252. DOI: $10.1080 / 10168730600699572$

Loayza, N. V. (1996). The economics of the informal sector: a simple model and some empirical evidence from Latin America. Carnegie-Rochester Conference Series on Public Policy, 45, 129-162.

Malaczewska, P. (2013). Useful government expenditure influence on the shadow economy. Quantitative Methods in economics, 14(2), 61-69,

Medina, L., \& Schneider, F. (2018). Shadow Economies Around the World: What Did We Learn Over the Last 20 Years? (Working Paper, No. WP/18/17). Retrieved from International Monetary Fund website:

https://www.imf.org/en/Publications/WP/Issues/2018/01/25/Sh adow-Economies-Around-the-World-What-Did-We-LearnOver-the-Last-20-Years-45583

Medina, L., \& Schneider, F. (2017). Shadow economies around the world: New results for 158 countries over 1991-2015 (Working Paper No. 6430). Retrieved from CESifo website: https://www.ifo.de/DocDL/cesifo1_wp6430.pdf

Mikulic, D., \& Nagyszombaty, A.G. (2013). Causes of the unofficial economy in new EU member states. Economic Research, 26(sup1), 29-44.

DOI: 10.1080/1331677X.2013.11517638

Nikopour, H., Habibullah, M., Schneider, F., \& Law, S. (2009). Foreign Direct Investment and Shadow Economy: A Causality
Analysis Using Panel Data (Paper No. 14485). Retrieved from MPRA website: https://mpra.ub.uni-muenchen.de/14485/

Piatkowski, M. (2002). The 'New Economy' and Economic Growth in Transition Economies: The Relevance of Institutional Infrastructure (Discussion Paper No.2002/062). Retrieved from WIDER website:

https://www.econstor.eu/bitstream/10419/52770/1/352846933. pdf

Schneider, F. (2000). Dimensions of the shadow economy. The Independent Review, 5(1), 81-91.

Schneider, F. (2005). Shadow economies around the world: What do we really know? European Journal of Political Economy, 21(3), 598-642. DOI: 10.1016/j.ejpoleco.2004.10.002

Schneider, F. (2011). Handbook on the Shadow Economy. Cheltenham, UK: Edward Elgar Publishing.

Schneider, F. (2015). Shadow economy and shadow labor market: The developments of the past 20 years. Perspectives of Economic Policy, 16(1), 3-25.

Schneider, F. (2017). Estimating a Shadow Economy: Results, Methods, Problems, and Open Questions. Open Economics, 1, 1-29. DOI: 10.1515/openec-2017-0001.

Schneider, F., \& Enste, D. H. (2000). Shadow Economies: Size, Causes, and Consequences. Journal of Economic Literature, 38(1), 77-114. DOI: 10.1257/jel.38.1.77

Schneider, F., \& Enste, D. H. (2013). The shadow economy: An international survey (2nd ed.). Cambridge, UK: Cambridge University Press.

Schneider, F., \& Hametner, B. (2013). The shadow economy in Colombia: size expand effects on economic growth. Peace Economics, Peace Science, and Public Policy, 20(2), 293-325.

Schneider, F., \& Williams, C.C. (2013). The Shadow Economy. London, UK: The Institute of Economic Affairs.

Tabaghua, S. (2018). Economic Growth in Transition Economies: Does investments matter? Proceedings of International Academic Conferences 7809587. London, UK: International Institute of Social and Economic Sciences.

Torgler, B., \& Schneider, F. (2009). The impact of tax morale and institutional quality on the shadow economy. Journal of Economic Psychology, 30(2), 228-245. DOI: 10.1016/j.joep.2008.08.004

Williams, C. C., \& Schneider, F. (2016). Measuring the Global Shadow Economy: The Prevalence of Informal Work and Labour. Cheltenham, UK: Edward Elgar Publishing.

World Bank. (2016). World Development Indicators. World Bank, Washington.

Wu, D. F., \& Schneider, F. (2019). Nonlinearity between the shadow economy and level of development (Working Paper WP/19/48). Retrieved from IMF website: https://www.imf.org/en/Publications/WP/Issues/2019/03/01/N onlinearity-Between-the-Shadow-Economy-and-Level-ofDevelopment-46618

Zaman, G., \& Goschin, Z. (2015). Shadow economy and economic growth in Romania. Cons and pros. Procedia Economics and Finance, 22, 80-87. DOI: 10.1016/S22125671(15)00229-4. 


\section{Appendix}

Countries are selected in this paper: Albania, Armenia, Azerbaijan, Belarus, Bulgaria, Cambodia, China, Croatia, Georgia, Hungary, Kazakhstan, Lao P.D.R., Moldova, Poland, Romania, Russia, Ukraine, and Vietnam. 